\title{
ASSOCIATION BETWEEN SOCIALIZATION AND THE USE OF MATERNITY WAITING HOME IN EAST ACEH
}

\author{
Atika Triwulan Dari \\ Graduate Program in Public Health, Universitas Sumatera Utara
}

\begin{abstract}
Background: Maternity waiting homes are residential facilities where women who live remotely can wait before giving birth at a hospital or health centre. The aim of implementing a maternity waiting home strategy is to reduce maternal and perinatal mortality by improving access to skilled birth attendance and emergency obstetric care, particularly for women in rural and remote areas. This study aimed to examine the association between socialization and the use of maternity waiting home in East Aceh.

Subjects and Method: This was a cross-sectional study carried out in four kesmas (community health center), in East Aceh. A sample of 130 pregnant mothers was selected for this study by stratified random sampling. The dependent variable was the use of maternity waiting home. The independent variable was socialization and family support. The data were collected by questionnaire and analyzed by a multiple logistic regression.

Results: Socialization was associated with an increased use of maternal waiting home (OR=14.17; $\mathrm{p}=0.002)$, after controlling from the effect of family support.

Conclusion: Socialization is associated with an increased use of maternal waiting home, after controlling for the effect of family support.
\end{abstract}

Keywords: maternity waiting home, socialization, family support.

\section{Correspondence:}

Atika Triwulan Dari. Graduate Program in Public Health, Universitas Sumatera Utara, Jalan Universitas No. 21, Kampus USU, Medan 20155, North Sumatera.

Email: atika.triwulandari@ymail.com.Mobile: 085260408583. 